\section{EFFECTS OF STORAGE TEMPERATURE AND FETAL CALF SERUM ON THE ENDOTHELIUM OF PORCINE AORTIC VALVES}

Endothelial integrity and function may be an important determinant for long-term success of allograft heart valves. To determine the optimal storage temperatures for preservation of long-term endothelial function in porcine aortic valves, different storage temperatures and times were investigated. Fresh valves were either (1) stored at $4^{\circ} \mathrm{C}$, with or without $10 \%$ fetal calf serum supplement, for $1,2,4,7,14,21$, or 28 days; (2) cryopreserved for 2 , 4, or 8 weeks at $-80^{\circ} \mathrm{C}$ or $-170^{\circ} \mathrm{C}$; (3) cryopreserved in long-term storage (as long as 1 year), with or without fetal calf serum, at $-170^{\circ} \mathrm{C}$. Viability of endothelial cells was assessed through measurement of the production of prostacyclin in basal and bradykinin-stimulated conditions, during in vitro incubation of the valve cusps at $37^{\circ} \mathrm{C}$. Endothelial morphologic variations in valves stored at $4^{\circ} \mathrm{C}$ were evaluated by scanning electron microscopy. With storage at $4^{\circ} \mathrm{C}$, after 4 days the valves already produced significantly less $(p<0.05)$ prostacyclin than fresh preparations in both basal $(0.21 \pm 0.04$ versus $3.56 \pm 0.03 \mathrm{ng}$ $\left.\cdot \mathrm{ml}^{-1} \cdot \mathrm{cm}^{-2}\right)$ and stimulated conditions $(4.17 \pm 0.36 \mathrm{vs} 24.23 \pm 1.83)$. Morphologic changes could not yet be distinguished with scanning electron microscopy at that time. When the storage period was extended, the levels of prostacyclin further diminished; after 14 days, prostacyclin release could no longer be detected. In cryopreserved valves, prostacyclin production was similar for as long as 2 weeks of storage either at $-80^{\circ} \mathrm{C}$ or at $-170^{\circ} \mathrm{C}$ in basal $(2.69 \pm 0.63$ vs $2.93 \pm 0.51)$ and stimulated $(16.43 \pm 3.19$ vs $16.50 \pm 2.57$, = 6) conditions. After 8 weeks, no prostacyclin release could be detected in valves stored at $-80^{\circ} \mathrm{C}$. After 6 months storage at $-170^{\circ} \mathrm{C}$, the prostacyclin production was significantly $(\boldsymbol{p}<\mathbf{0 . 0 5}$ ) reduced compared with fresh valves; it then remained constant for as long as 1 year. The valves stored with fetal calf serum produced significantly $(p<0.05)$ less prostacyclin than did those without fetal calf serum. For longer cryopreserved banking, we recommend storing heart valves at $-170^{\circ} \mathrm{C}$ instead of at $-80^{\circ} \mathrm{C}$ to maintain viability of endothelial cells. Fetal calf serum would harm endothelial viability during long-term cryopreservation. (J THORAC CARDIOVASC SURG 1996;111:218-30)

Xiao J. Feng, MD, PhD, ${ }^{\text {a }}$ Cor E. J. Van Hove,

Paul J. Walter, MD, PhD, FACS, and Arnold G. Herman, MD, PhD, ${ }^{\mathrm{b}}$ Antwerp, Belgium
B ecause the supply of homograft heart valves is imited and in most institutions homograft valves are not immediately implanted after procurement, storage of heart valves has become essential. At

From the Departments of Cardiac Surgery ${ }^{\mathrm{a}}$ and Pharmacology ${ }^{\mathrm{b}}$, Faculty of Medicine, University of Antwerp (UIA), AntwerpWilrijk, Belgium.

Received for publication Nov. 21, 1994.

Accepted for publication Feb. 22, 1995.

Address for reprints: Xiao J. Feng, MD, Department of Pharmacology, University of Antwerp (UIA), Universiteitsplein 1, B-2610 Wilrijk, Belgium.

Copyright (C 1996 by Mosby-Year Book, Inc.

$0022-5223 / 96 \$ 5.00+0 \quad \mathbf{1 2 / 1 / 6 4 3 4 2}$ present, centers that use many homograft valves and therefore have short delay periods for implantation continue to store homografts at $4^{\circ} \mathrm{C}$ for about a week (Yacoub $\mathrm{MH}$, personal communication). Most other centers prefer cryopreservation of homograft valves. 1,2

Cryopreservation of valves includes a freezing procedure, a storage process, and a thawing protocol. The influences of freezing program and thawing conditions on the endothelial viability of heart valves have been described previously. ${ }^{3}$ The effects of both temperature and duration of storage are described in this article.

In the cryopreservation of homograft valves, controversies exist regarding how low the storage tem- 
perature should be. Cryopreserved valves are mainly stored at $-80^{\circ} \mathrm{C}$ in a solid carbon dioxide refrigerator or at $-196^{\circ} \mathrm{C}$ in liquid nitrogen. Yankah (personal communication) has been storing homograft valves at $-80^{\circ} \mathrm{C}$ for the last 5 to 7 years and intends to continue storing these valves for another 5 years. Other centers, such as CryoLife, Inc., in the United States, cryopreserve valves in liquid nitrogen. This procedure is also included in the guidelines of Euro Transplant, Rotterdam, The Netherlands.

Storage in a refrigerator at $-80^{\circ} \mathrm{C}$ in the operation room offers practical advantages for surgeons. This type of storage permits inspection of the valves and makes it easier to determine the size of the homograft valve to be used after intraoperative sizing of the aortic root. Preoperative echocardiographic evaluation of aortic root size often fails to predict the correct valve size.

On the other hand, Lange and Hopkins ${ }^{4}$ indicate that some physicochemical changes still continue at $-130^{\circ} \mathrm{C}$, and that even for the optimal preservation of the interstitial matrix the storage temperature should be below $-130^{\circ} \mathrm{C}$. Because self-repair by fibroblasts of the implanted homograft valve could determine its ultimate durability in the host, and because the endothelium could protect against thrombus formation and also prevent the loss of subendothelial structures, the preimplantation viability of all cells comprising the homograft may be critical. We therefore compared the effect of three different storage temperatures, $4^{\circ} \mathrm{C},-80^{\circ} \mathrm{C}$, and $-170^{\circ} \mathrm{C}$, and various storage periods on prostacyclin $\left(\mathrm{PGI}_{2}\right)$ production in vitro as a marker of viability in the endothelial cells of porcine aortic valve cusps. We selected endothelial function for the assessment of homograft cell viability after storage because an intact endothelium not only helps prevent intravascular thrombosis but also can contribute to fibroblast alimentation from the bloodstream. Furthermore, the endothelium is the most vulnerable component of the aortic valve cusp and therefore can be used as a sensitive indicator of overall cell survival. It should be noted that storing the valves in liquid nitrogen at vapor-phase temperature $\left(-190^{\circ} \mathrm{C}\right.$ to $\left.-150^{\circ} \mathrm{C}\right)$ is traditionally referred to as storage in liquid nitrogen at $-196^{\circ} \mathrm{C}$. In our study, we cryopreserved valves at $-170^{\circ} \mathrm{C}$, the temperature we also use in our clinical homograft valve bank.

\section{Material and methods}

The porcine aortic valves were stored for various periods at $4^{\circ} \mathrm{C}$ in the nutrient medium or cryopreserved at $-80^{\circ} \mathrm{C}$ and $-170^{\circ} \mathrm{C}$ in cryopreservation freezing medium after a controlled-rate freezing process.

Valve preparation. Fresh porcine aortic valves were obtained from a local slaughterhouse. Hearts were removed as nearly aseptically as possible from pigs (weight 100 to $120 \mathrm{~kg}$, age 180 to 210 days) within 20 minutes after death. The aortic valve, along with 2 to $3 \mathrm{~cm}$ of ascending aorta and 1 to $1.5 \mathrm{~cm}$ of ventricular myocardium, was quickly excised from the heart with sterile material in a clean area of the slaughterhouse. The valves were placed carefully in ice-cold RPMI 1640 tissue medium and then transported to the laboratory within 40 minutes. In the laboratory, each valve was longitudinally separated into three tissue pieces. Each tissue piece consisted of the corresponding cusp with $3 \mathrm{~cm}$ adjacent aortic wall and some myocardium. A 7-0 Prolene suture (Ethicon, Inc., Somerville, N.J.) was then passed through the center of the free edge of the cusp to enable easy lifting from one solution to another. Either the distribution of the cusps into control and test groups was fully random or one of the three cusps of a single valve served as control and the other two were used as test material.

\section{Storage procedures}

Storage at $4^{\circ} \mathrm{C}$. The tissue piece was put into a sterile plastic container containing $100 \mathrm{ml}$ RPMI 1640 tissue culture medium at $4^{\circ} \mathrm{C}$ with or without $10 \%$ fetal calf serum (FCS) and stored for various periods (1, 2, 4, 7, 14, 21 , or 28 days). Renewal of the medium was carried out every week until the end of the storage period for cusps stored longer than 7 days.

Cryopreservation at $-80^{\circ} \mathrm{C}$ and $-170^{\circ} \mathrm{C}$. Freezing conditions and techniques for cryopreservation have been described elsewhere. ${ }^{3}$ Two hemofreeze bags ( $\mathrm{GmbH} \&$ Co. KG, Hechingen, Germany) filled with $100 \mathrm{ml}$ medium were used as the packaging material. Dimethyl sulfoxide was added at room temperature in a concentration of $10 \%$ as a cryoprotective agent. The packed valves were kept at $4^{\circ} \mathrm{C}$ for 20 minutes of equilibration. The valves were frozen in a freezing chamber with a programmable temperature controller. Temperature was monitored with a temperature probe. A freezing rate of $-1^{\circ} \mathrm{C} / \mathrm{min}$ at the site of the tissue was achieved. On termination of the controlled freezing program at $-80^{\circ} \mathrm{C}$, the valves were immediately removed from the freezing chamber and cryopreserved either in a mechanical freezer at $-80^{\circ} \mathrm{C}$ or in a liquid nitrogen tank in the vapor phase at $-170^{\circ} \mathrm{C}$.

The valves were stored both at $-80^{\circ} \mathrm{C}$ or $-170^{\circ} \mathrm{C}$ for 2 , 4 , and 8 weeks. Longer storage periods of 6 months and 1 year were also studied for valves stored at $-170^{\circ} \mathrm{C}$. For long-term storage, cryopreservation solutions with or without $10 \%$ FCS supplement were also compared.

Estimation of $\mathrm{PGI}_{2}$ production. After different storage periods, rapid-rate thawing and gentle dilution procedure of the cryoprotective agent (dimethyl sulfoxide) were used for all cryopreserved valves. ${ }^{3}$ Thawing was performed by completely immersing the frozen valves with their internal packaging in a large volume of water at $40^{\circ} \mathrm{C}$. Only 2 to 3 minutes was required to turn the ice to slush. Dimethyl sulfoxide concentration was decreased from $10 \%$ to $7.5 \%$, $5 \%, 2.5 \%$, and finally $0 \%$. Each step took only 1.5 to 2 minutes. For all tested valves, the cusps were dissected 
free from the valve tissue for estimation of $\mathrm{PGI}_{2}$ production.

Incubation for assessment of basal and bradykininstimulated $\mathrm{PGI}_{2}$ production has been described elsewhere. $^{3,5}$ The incubation medium was kept at $37^{\circ} \mathrm{C}$ in the test tubes, each of which contained $2.5 \mathrm{ml}$ of RPMI 1640 supplemented with $1 \%$ (weight/volume) bovine serum albumin and $2 \%$ (volume/volume) $1 \mathrm{~mol} / \mathrm{L}$ phosphate buffer ( $\mathrm{pH} 7.4)$. After each cusp was dissected free from the valve tissue, it was lifted every 15 minutes from one test tube to another with a no-touch technique that used 7-0 Prolene suture for 20 periods totaling 300 minutes. $\mathrm{PGI}_{2}$ release into the incubation medium of each of these test tubes was measured by radioimmunoassay of 6-oxo$\mathrm{PGF}_{1 \alpha}$, the stable metabolite of $\mathrm{PGI}_{2}{ }^{6}{ }^{6}$ To stop continued $\mathrm{PGI}_{2}$ production by shed endothelial cells, indomethacin (final concentration $10 \mu \mathrm{g} / \mathrm{ml}$ ) was immediately added to the medium after the cusp had been removed from the test tube.?

Previous experiments demonstrated that during the incubation period, spontaneous release of $\mathrm{PGI}_{2}$ by the fresh cusp follows a bell-shaped production curve. From 270 minutes onward, the $\mathrm{PGI}_{2}$ release, although slightly diminished, is no longer significantly different from the previous incubation period and is therefore referred to as basal production. This period allowed us to study $\mathrm{PGI}_{2}$ production stimulated by a receptor-mediated mechanism such as bradykinin (final concentration $10 \mu \mathrm{mol} / \mathrm{L}$ ), ${ }^{8}$ which was added to the incubation medium during the 270 to 285-minute incubation period.

Calculation of endothelial cell surface area of the cusp. To calculate the amount of $\mathrm{PGI}_{2}$ produced per square centimeter of the cusp surface, the ratio of the weight of the total dried cusp to its measured surface area was used. This was done after the $\mathrm{PGI}_{2}$ estimation by weighing a circular piece of the cusp, punched out by a circular knife (diameter $0.5 \mathrm{~cm}$ ), of which the surface area was known $\left(0.3925 \mathrm{~cm}^{2}\right)$.

Statistical analysis. A paired Student's $t$ test (5\% level of significance) was used to compare the basal and stimulated $\mathrm{PGI}_{2}$ levels because these observations were made in the same specimens. To compare the $\mathrm{PGI}_{2}$ release between cusps stored according to different storage treatments, analysis of variance was used.

Scanning electron microscopy (SEM). The endothelial integrity of valves stored at $4^{\circ} \mathrm{C}$ for $2,4,7,14$, and 21 days was examined by SEM. The preparation of the tissue specimens and the quantification of the endothelial damage were similar to previously descriptions. ${ }^{5}$ The valve cusps were fixed with $2.5 \%$ glutaraldehyde in $0.1 \mathrm{~mol} / \mathrm{L}$ cacodylate buffer; specimens were postfixed in $1 \%$ osmium tetroxide in $0.1 \mathrm{~mol} / \mathrm{L}$ cacodylate buffer for 2 hours and then rinsed again in cacodylate buffer with $7.5 \%$ saccharose. Specimens were dehydrated in an ascending series of ethanol up to $100 \%$ strength and $100 \%$ isoamylacetate, followed by critical-point drying in a Balzer apparatus with carbon dioxide used as transitional fluid. Each valve cusp was longitudinally divided into two parts. All surfaces were mounted on stubs with double-faced tape, sputter coated with a $15 \mathrm{~nm}$ layer of gold, and subsequently examined and photographed in a JEOL $1200 \mathrm{EX}$ microscope equipped with scanning image device
EM-ASIDIO (JEOL Ltd., Tokyo, Japan) operating at 40 $\mathrm{kV}$. The ventricular and aortic surfaces of each part were examined. At least five random fields, only from the center of each piece, were sampled and scored by an independent observer with ratings of,+++ , and +++ for each of the following variables: (1) overall endothelial coverage, (2) intercellular gaps, (3) microvilli, (4) membrane damage, (5) basal lamina, and (6) exposure of collagen fibrils.

\section{Results}

\section{$\mathrm{PGI}_{2}$ production}

Storage at $4^{\circ} \mathrm{C}$

ONE TO 21-DAY PERIOD. The $\mathrm{PGI}_{2}$ production levels of valves previously stored at $4^{\circ} \mathrm{C}$ for various periods were compared to that of fresh valves used as a control. As shown in Fig. $1, \mathrm{PGI}_{2}$ production by fresh valve cusps showed a bell-shaped pattern. It rose to a maximum value during the 120 to $135-$ minute period of incubation and then decreased gradually to a steady basal level, at which moment it could still be stimulated by means of a bradykinin receptor-mediated mechanism (Fig. 1, $A$ ). For the stored valves, both the spontaneous release and the bradykinin-stimulated production diminished as the duration of the storage period increased.

After 1 day of storage (Fig. $1, B$ ), the valves retained $93 \% \pm 4.2 \%$ of the basal release (measured in the 15 -minute period before stimulation) and $74 \% \pm 3.8 \%$ of the stimulated release as compared with fresh cusps. There was no difference in maximum, basal, and stimulated $\mathrm{PGI}_{2}$ production levels compared with control values, although the bell-shaped pattern was delayed for about 40 to 60 minutes.

After 2 days of storage (Fig. 1,C), the basal $\mathrm{PGI}_{2}$ release still maintained its bell-shaped pattern, although the maximum production was significantly $(p<0.05)$ less than in fresh valves. The basal and stimulated $\mathrm{PGI}_{2}$ release levels were reduced to $63 \%$ $\pm 2.8 \%$ and $41 \% \pm 1.7 \%(p<0.05)$, respectively, of the production observed in the fresh valves.

After 4 days of storage (Fig. 1, D), the bell-shaped curve was no longer present. The basal release could hardly be detected, and after stimulation the $\mathrm{PGI}_{2}$ production was reduced to $17 \% \pm 1.5 \%$ of the control value.

For as long as 7 days of storage, stimulated production of $\mathrm{PGI}_{2}$ could still be observed (Fig. 1 $E)$. After 14 days of storage, both spontaneous and stimulated $\mathrm{PGI}_{2}$ production levels were near the detection limit of the radioimmunoassay (Fig. 1, F). 

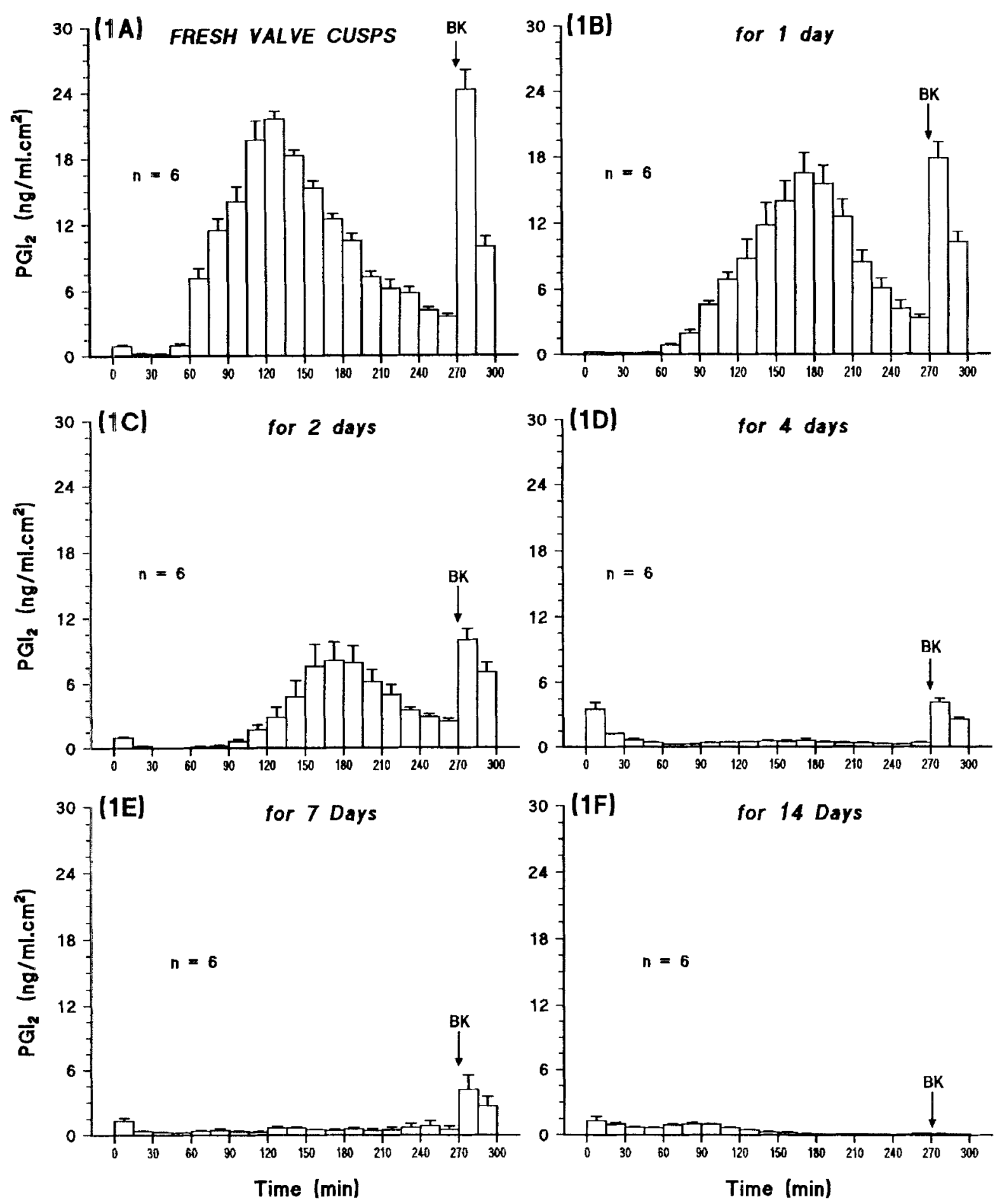

Fig. 1. $\mathrm{PGI}_{2}$ production during 300 minutes of incubation by valve cusps stored for 1 (B), 2 (C), 4 (D), 7 (E), and 14 (F) days at $4^{\circ} \mathrm{C}$ compared with fresh valve cusps (A). The $x$ axis refers to the time of the consecutive incubation periods. The $y$ axis displays the $\mathrm{PGI}_{2}$ content in the incubation medium within 15 minutes of incubation. Bradykinin $(B K, 10 \mu \mathrm{mol} / \mathrm{L}$ ) was added to the medium as the agonist during the 270 - to 285-minute incubation. The bell-shaped curve in $\mathbf{A}$ represents spontaneous $\mathrm{PGI}_{2}$ production by the cusps. 
Table I. $P G I_{2}$ production by porcine aortic valve cusps after storage at $4^{\circ} \mathrm{C}$ for different periods in RPMI 1640 medium with or without FCS for different periods (in nanograms per milliliter per square centimeter; $n \geq 6$ )

\begin{tabular}{|c|c|c|c|c|}
\hline & \multicolumn{2}{|c|}{ Without FCS } & \multicolumn{2}{|c|}{ With FCS } \\
\hline & Basal & Stimulated & Basal & Stimulated \\
\hline Control & $3.56 \pm 0.30$ & $24.23 \pm 1.83^{*}$ & $3.56 \pm 0.30$ & $24.23 \pm 1.83^{*}$ \\
\hline 2 days & $2.50 \pm 0.25$ & $9.96 \pm 1.00^{*}$ & $3.48 \pm 1.49$ & $10.39 \pm 1.50^{*}$ \\
\hline 4 days & $0.42 \pm 0.05$ & $4.17 \pm 0.36^{*}$ & $0.41 \pm 0.11$ & $4.01 \pm 0.063^{*}$ \\
\hline 7 days & $0.52 \pm 0.30$ & $4.15 \pm 1.34^{*}$ & $0.35 \pm 0.07$ & $2.91 \pm 0.55^{*}$ \\
\hline 14 days & $0.15 \pm .008$ & $0.17 \pm 0.04$ & $0.13 \pm 0.003$ & $0.11 \pm 0.07$ \\
\hline 21 days & $0.12 \pm 0.03$ & $0.13 \pm 0.03$ & $0.07 \pm 0.01$ & $0.09 \pm 0.01$ \\
\hline
\end{tabular}

* $\mathrm{PGI}_{2}$ significantly $(p<0.05)$ increased after stimulation.

Table II. $\mathrm{PGI}_{2}$ production by porcine aortic valves after storage of time at $4^{\circ} \mathrm{C}$ for different periods in RPMI 1640 medium without or with renewal of the medium (nanograms per milliliter per square centimeter; $n \geq 6$ )

\begin{tabular}{|c|c|c|c|c|}
\hline & \multicolumn{2}{|c|}{ Without renewal } & \multicolumn{2}{|c|}{ With renewal $*$} \\
\hline & Basal & Stimulated & Basal & Stimulated \\
\hline Control & $2.88 \pm 0.19$ & $18.55 \pm 2.07 \dagger$ & $2.88 \pm 0.19$ & $18.55 \pm 2.07 \dagger$ \\
\hline 7 days & $0.52 \pm 0.30$ & $4.15 \pm 1.34 \dagger$ & - & - \\
\hline 14 days & $0.15 \pm 0.008$ & $0.17 \pm 0.04$ & $0.90 \pm 0.14$ 韦 & $2.38 \pm 0.26+\div$ \\
\hline 21 days & $0.12 \pm 0.03$ & $0.13 \pm 0.03$ & $0.11 \pm 0.03$ & $1.65 \pm 0.36 t \div$ \\
\hline 28 days & - & - & $0.08 \pm 0.02$ & $0.43 \pm 0.9 \dagger$ \\
\hline
\end{tabular}

${ }^{*}$ Medium was replaced with fresh medium every 7 days.

†After stimulation by bradykinin, $\mathrm{PGI}_{2}$ was significantly $(p<0.05)$ increased compared with basal level.

$\Varangle \mathrm{PGI}_{2}$ was significantly $(p<0.05)$ higher than the $\mathrm{PGI}_{2}$ released by the group stored for the same period without renewal of medium.

INFLUENCE OF FCS. Valves stored at $4^{\circ} \mathrm{C}$ with and without FCS added to the storage medium were also compared. Inclusion of FCS $(10 \%)$ in the storage medium did not significantly affect the $\mathrm{PGI}_{2}$ production (Table I).

RENEWAL OF MEDIUM. Regular renewal of the storage medium with fresh culture medium resulted in a longer preservation of bradykinin-stimulated $\mathrm{PGI}_{2}$ production. After 28 days of storage in which the storage medium was replaced with fresh medium every 7 days, bradykinin could still significantly increase the $\mathrm{PGI}_{2}$ production (Table II), whereas this was no longer possible with the cusps kept at $4^{\circ} \mathrm{C}$ for 14 days in the same medium without renewal. Spontaneous release was less affected by the medium renewal and decreased as the duration of the storage increased.

Cryopreservation at $-80^{\circ} \mathrm{C}$ and $-170^{\circ} \mathrm{C}$

SHORT-TERM STORAGE AT $-80^{\circ} \mathrm{C}$ AND $-170^{\circ} \mathrm{C}$ (AS LONG AS 8 WEEKS). Cryopreservation at either $-80^{\circ} \mathrm{C}$ or $-170^{\circ} \mathrm{C}$ for as long as 2 weeks showed comparable $\mathrm{PGI}_{2}$ production levels (Fig. 2, $B$ and $C)$. Although the spontaneous release of $\mathrm{PGI}_{2}$ was significantly diminished, the stimulated production was similar to that of fresh valves (Fig. 2, $A$ ).

Cryopreservation for 4 weeks at $-80^{\circ} \mathrm{C}$ significantly reduced both spontaneous and stimulated
$\mathrm{PGI}_{2}$ production as compared with fresh valves and valves cryopreserved at $-170^{\circ} \mathrm{C}$ (Fig. 2, $D$ and $E$ ).

After 8 weeks of storage at $-80^{\circ} \mathrm{C}$, hardly any $\mathrm{PGI}_{2}$ production (either spontaneous or stimulated) could be detected (Fig. 2, F). In contrast, valves cryopreserved at $-170^{\circ} \mathrm{C}$ for 4 and 8 weeks still released $\mathrm{PGI}_{2}$ (Fig. 2, $G$ ), and this release was comparable to production by the valves cryopreserved at $-170^{\circ} \mathrm{C}$ for 2 weeks (Fig. 2, E).

LONG-TERM STORAGE AT $-170^{\circ} \mathrm{C}$ ( 6 MONTHS TO 1 YEAR). Long-term preservation in liquid nitrogen at vapor phase significantly $(p<0.05)$ reduced both basal and stimulated $\mathrm{PGI}_{2}$ production after 6 months compared with fresh valve cusps (Fig. 3 and Table III) but then remained constant for as long as 1 year. When FCS was included in the cryopreservation medium, the $\mathrm{PGI}_{2}$ production was significantly $(p<0.05)$ reduced at 6 and 12 months of storage compared with the same storage period without FCS.

SEM of $4^{\circ} \mathrm{C}-$ STORED VALVES. The results of SEM are shown in Table IV. The morphologic alterations of the endothelium appeared later than the biochemical changes (decrease of $\mathrm{PGI}_{2}$ production). For periods of storage at $4^{\circ} \mathrm{C}$ as long as 4 days, SEM could not clearly distinguish variations of the endo- 

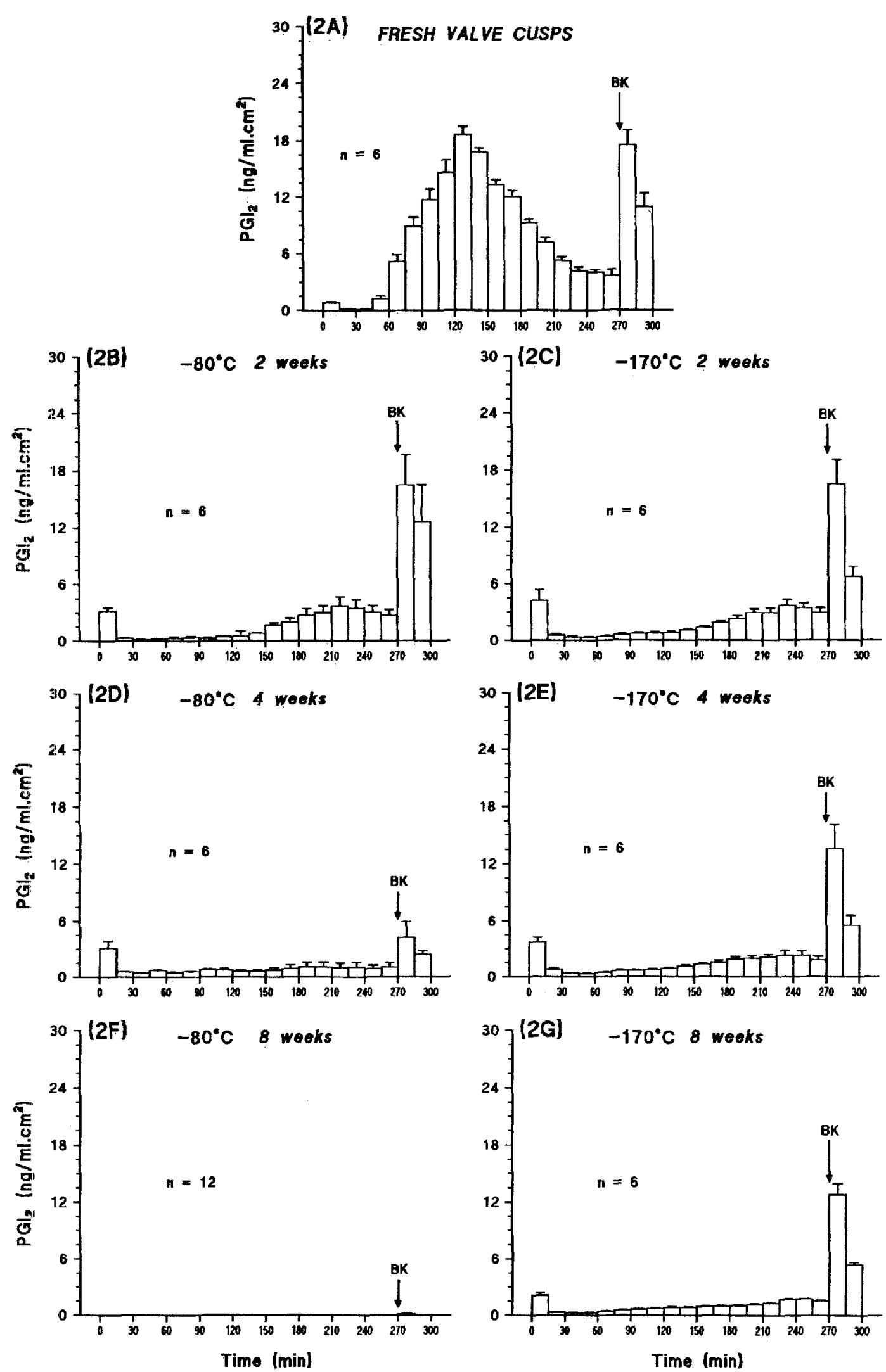

Fig. 2. $\mathrm{PGI}_{2}$ production by valve cusps cryopreserved for 2 (B and $\mathbf{C}$ ), 4 (D and $\mathbf{E}$ ), and 8 (F and $\mathbf{G}$ ) weeks at $-80^{\circ} \mathbf{C}(\mathbf{B}, \mathbf{D}$, and $\mathbf{F})$ and $-170^{\circ} \mathbf{C}(\mathbf{C}, \mathbf{E}$, and $\mathbf{G})$ compared with fresh valve cusps (A). The $x$ axis refers to the time of the consecutive incubation periods. The $y$ axis displays the $\mathrm{PGI}_{2}$ content in the incubation medium within 15 minutes of incubation. Bradykinin $(B K, 10 \mu \mathrm{mol} / \mathrm{L})$ was added to the medium as the agonist during the 270- to 285-minute period of incubation. The bell-shaped curve in A represents spontaneous $\mathrm{PGI}_{2}$ production by the cusps. 

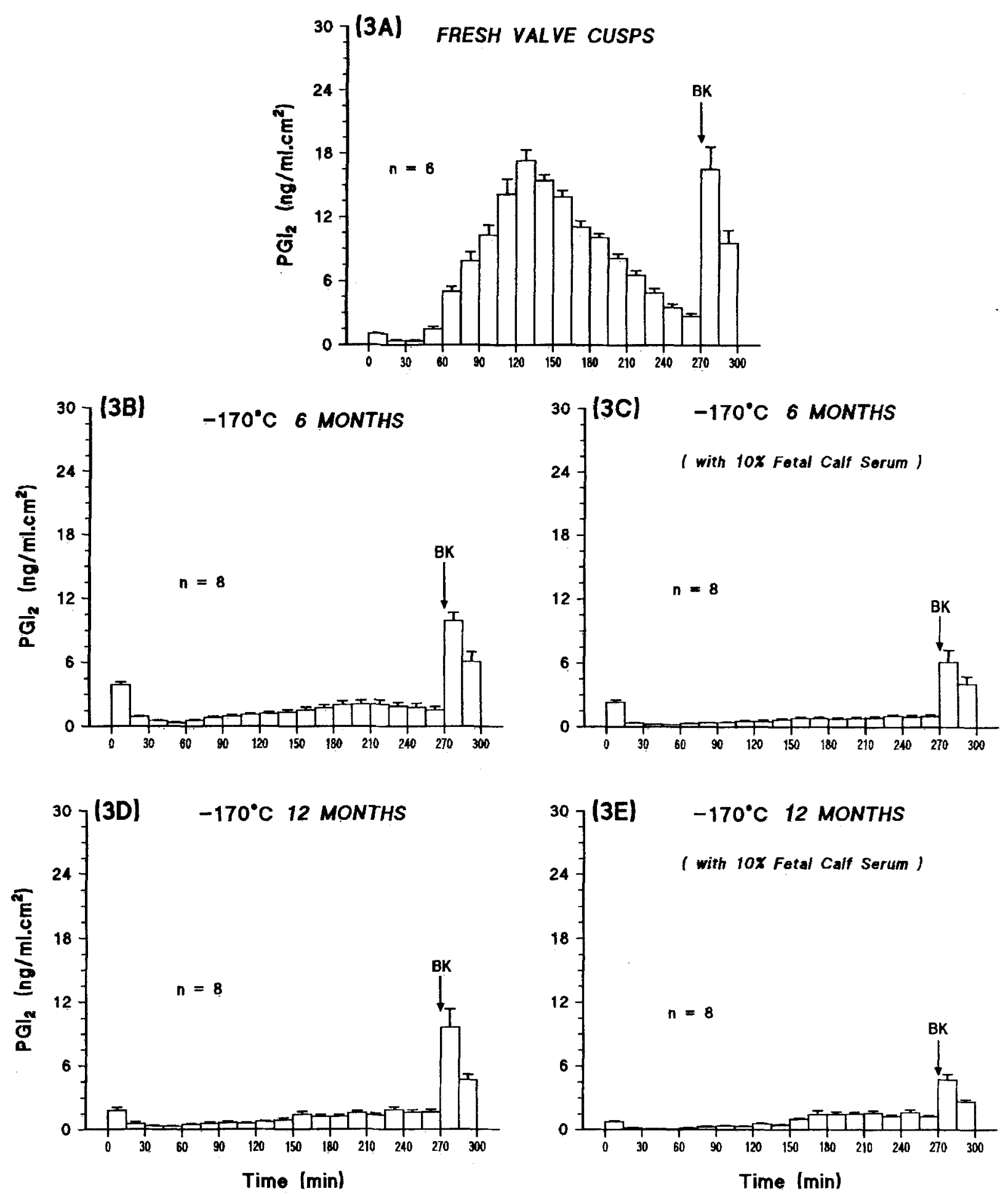

Fig. 3. $\mathbf{P G I}_{2}$ production by valve cusps cryopreserved for 6 months ( $\mathbf{B}$ and $\left.\mathbf{C}\right)$ or 1 year $(\mathbf{D}$ and $\mathbf{E})$ with $(\mathbf{C}$ and E) or without (B and D) FCS at $-170^{\circ} \mathrm{C}$ compared with fresh valve cusps (A). The $x$ axis refers to the time of the consecutive incubation periods. The $y$ axis displays the $\mathbf{P G I}_{2}$ content in the incubation medium within 15 minutes of incubation. Bradykinin $(B K, 10 \mu \mathrm{mol} / \mathrm{L})$ was added to the medium as the agonist during the 270 - to 285-minute period of incubation. The bell-shaped curve in $\mathbf{A}$ represents spontaneous $\mathrm{PGI}_{2}$ production by the cusps. 
Volume 111, Number 1

Table III. $\mathrm{PGI}_{2}$ production by porcine aortic valves after storage in liquid nitrogen at vapor phase at $-170^{\circ} \mathrm{C}$ for as long as 1 year with or without FCS (in nanograms per milliliter per square centimeter) $(n>6)$.

\begin{tabular}{|c|c|c|c|c|}
\hline & \multicolumn{2}{|c|}{ Without FCS } & \multicolumn{2}{|c|}{ With FCS } \\
\hline & Basal & Stimulated & Basal & Stimulated \\
\hline Control & $2.73 \pm 0.26$ & $16.55 \pm 2.12$ & $2.73 \pm 0.26$ & $16.55 \pm 2.12$ \\
\hline $1 / 2 \mathrm{yr}$ & $2.54 \pm 0.33^{*}$ & $9.94 \pm 0.77^{* \dagger}$ & $1.02 \pm 0.17 \dagger$ & $6.13 \pm 1.15 \dagger$ \\
\hline $1 \mathrm{yr}$ & $1.68 \pm 0.24$ & $9.62 \pm 1.71^{*} \dagger$ & $1.24 \pm 0.13 \dagger$ & $4.73 \pm 0.49 \dagger$ \\
\hline
\end{tabular}

After stimulation by bradykinin, $\mathrm{PGI}_{2}$ could be significantly $(p<0.05)$ increased as compared to basal in all groups

${ }^{*} \mathrm{PGI}_{2}$ was significantly $(p<0.05)$ higher than $\mathrm{PGI}_{2}$ released by the group cryopreserved for the same period with FCS.

$\dagger \mathrm{PGI}_{2}$ production was significantly less than control values.

Table IV. Evaluation by SEM of surface morphologic characteristics of porcine aortic valves after storage at $4^{\circ} \mathrm{C}$ for different periods

\begin{tabular}{cccccc}
\hline $\begin{array}{c}\text { Storage } \\
\text { time }\end{array}$ & $\begin{array}{c}\text { Endothelium } \\
\text { coverage }\end{array}$ & $\begin{array}{c}\text { Intercellular } \\
\text { gaps }\end{array}$ & $\begin{array}{c}\text { Membrane } \\
\text { damage }\end{array}$ & $\begin{array}{c}\text { Basal } \\
\text { lamina }\end{array}$ & $\begin{array}{c}\text { Fibrils } \\
\text { exposure }\end{array}$ \\
\hline Fresh & +++ & 0 & 0 & 0 & 0 \\
2 day & +++ & \pm & \pm & 0 & 0 \\
4 days & +++ & + & \pm & 0 & 0 \\
7 days & ++ & + & ++ & + & + \\
14 days & + & 0 & +++ & + & +++ \\
21 days & 0 & + & + & ++ \\
\hline
\end{tabular}

+++ , Strongly present; 0 , absent; \pm , present or absent; ++ , definitely present; + , present to some extent,

thelium. Intact endothelium with numerous microvilli covered the surface of the cusps; almost no subendothelial tissue could be observed, and intercellular gaps were occasionally found. Even after 7 days of storage, most areas on the surface of valve cusps were still covered by endothelial cells (Fig. 4), Slight damage was seen in some areas (e.g. the shape of cells had changed, and intercellular gaps and retraction fibers revealing underlying basal lamina could be observed).

The valves stored at $4^{\circ} \mathrm{C}$ for 14 days showed a damaged endothelial surface (Table IV). More than $50 \%$ of the endothelial cells were destroyed (displayed numerous holes in the cell membrane; Fig. 5, $A$ ), endothelial cells had an abnormal arrangement with an abnormal cell shape, and large intercellular gaps revealing basement membrane could be detected (Fig. 5, B). In some areas, endothelial cells were lost (Fig. 5, C).

It was difficult to find morphologically intact endothelial cells on the surface of the valves after 21 days of storage at $4^{\circ} \mathrm{C}$. Deendothelialization was common in most areas, and underlying collagen fibers were often completely exposed (Table IV). A few scattered remnants and shriveled endothelial cells could be found in some fields (Fig. 6).

\section{Discussion}

Depending on the preservation methods used, cells of the homograft valve can be damaged, and this damage will affect valve survival in the recipient after implantation. When survival results of implanted valve homografts are evaluated, it is therefore necessary to distinguish among viable, nonviable, and fresh homograft valves. ${ }^{9}$

Comparing three different storage temperatures $\left(4^{\circ} \mathrm{C},-80^{\circ} \mathrm{C}\right.$, and $\left.-170^{\circ} \mathrm{C}\right)$, the main advantage of storage in the unfrozen state at $4^{\circ} \mathrm{C}$ is the avoidance of damage by the formation of ice crystals; the disadvantage however, is limitation of storage duration. Our study demonstrates that after 24 hours of storage in a refrigerator at $4^{\circ} \mathrm{C}$, endothelial cells of porcine aortic valve cusps retain 93\% (basal) and $74 \%$ (stimulated) $\mathrm{PGI}_{2}$ production compared with fresh valves. After as long as 48 hours of storage, $\mathrm{PGI}_{2}$ production was reduced to $63 \%$ (basal) and $41 \%$ (stimulated), respectively. After 4 days at $4^{\circ} \mathrm{C}$, the capacity of the endothelial cells to produce $\mathrm{PGI}_{2}$ had sharply declined. Yankah and associates, ${ }^{10}$ by means of the dye-exclusion test, found $76 \%, 65 \%$, and $53 \%$ viable endothelial cells after storage at $4^{\circ} \mathrm{C}$ for 2,20 , and 30 hours, respectively. Clearly, endothelium loses its viability within a short time 


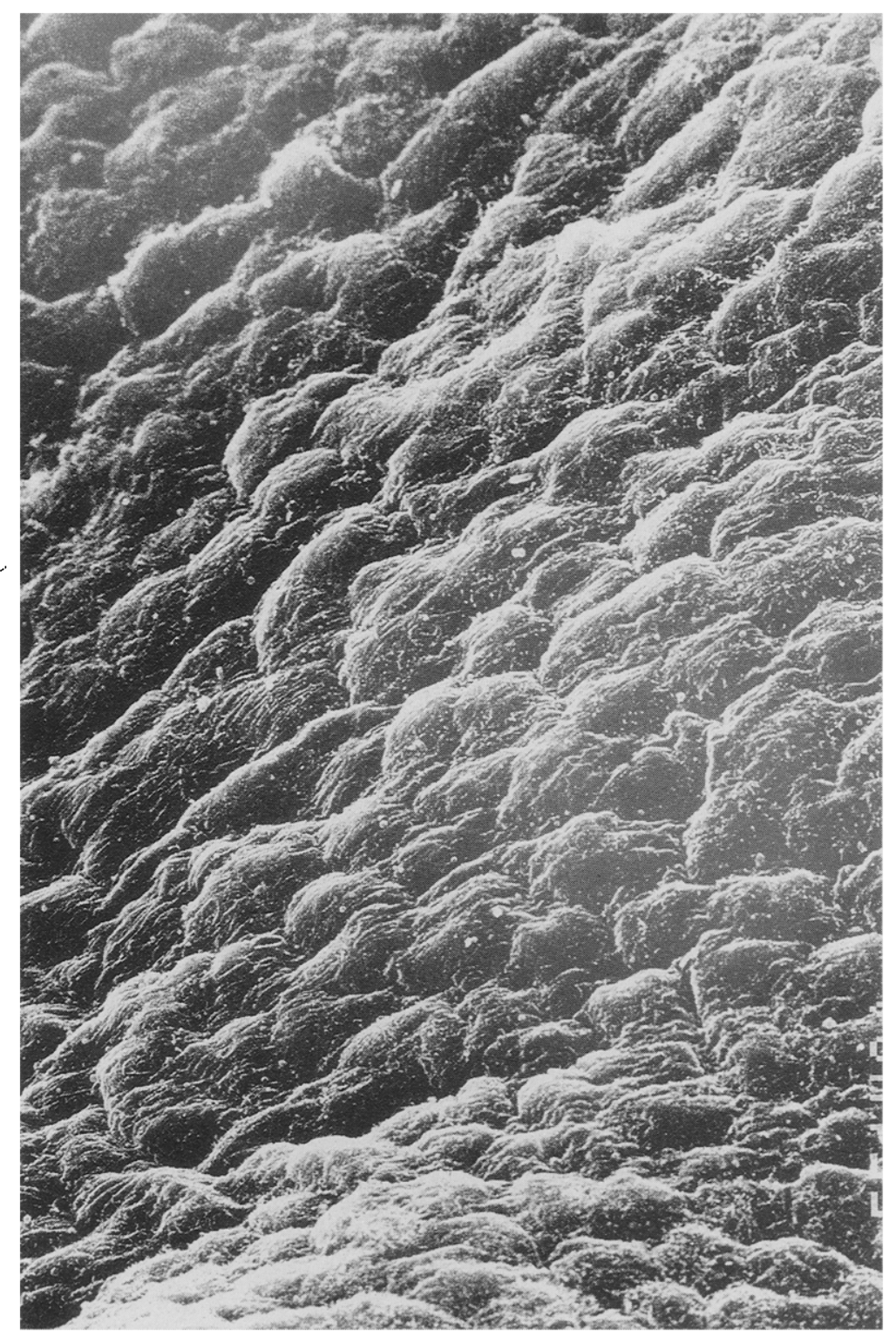

Fig. 4. SEM photograph of valves stored at $4^{\circ} \mathrm{C}$ in RPMI 1640 medium for 7 days. Most of the surface of valve cusp was covered by morphologically normal endothelium (original magnification $\times 800$ ).

when stored at $4^{\circ} \mathrm{C}$. Our study on storage at $4^{\circ} \mathrm{C}$ also indicated that a functional alteration of endothelial cells ( $\mathrm{PGI}_{2}$ production) occurred earlier than pronounced morphologic changes. After 1 week of storage at $4^{\circ} \mathrm{C}$, SEM of the valves still revealed a semiconfluent layer of endothelial cells even though their biochemical function had already decreased significantly.

Viability of fibroblasts of heart valves stored at $4^{\circ} \mathrm{C}$ has been previously studied. Yankah and Hetzer, ${ }^{10}$ with the dye-exclusion technique, showed that $80 \%$ of the fibroblasts were viable after 30 hours of storage at $4^{\circ} \mathrm{C}$. Mochtar and colleagues ${ }^{11}$ stored canine valves at $4^{\circ} \mathrm{C}$ and, by means of the technique of autoradiograph protein synthesis, that fibroblasts were only viable for 1 week. They could not reproduce the results of high viability after storage at $4^{\circ} \mathrm{C}$ for more than 1 week reported by Al-Janabi and coworkers. ${ }^{12}$ The observation by Mochtar and colleagues ${ }^{11}$ on fibroblast viability are similar to our findings on endothelial cell $\mathrm{PGI}_{2}$ production (Table II), and both indicate a rapid 

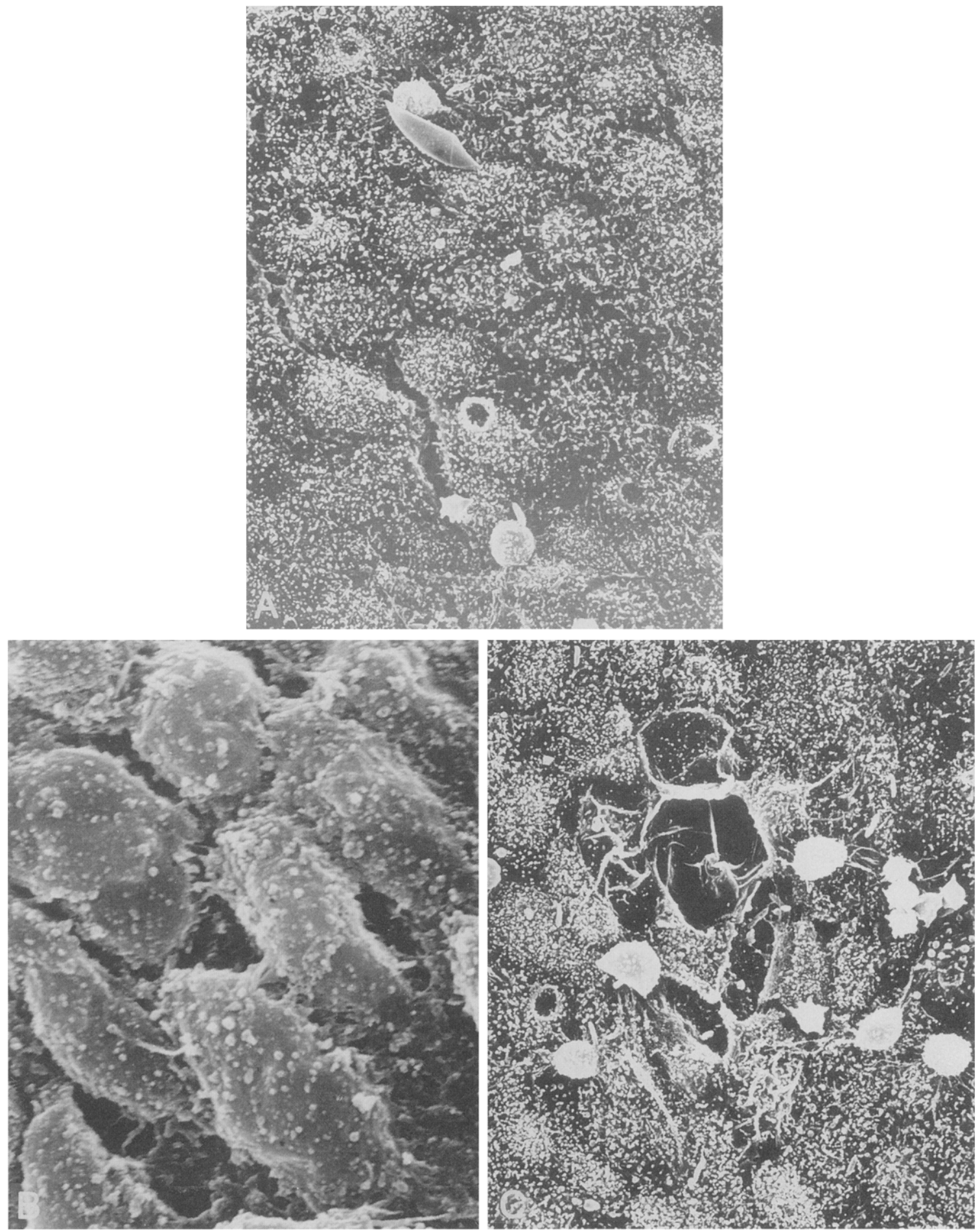

Fig. 5. SEM photographs of valves stored at $4^{\circ} \mathrm{C}$ in RPMI 1640 for 14 days. A, Many holes in the membrane of the endothelial cells (original magnification $\times 600$ ). B, Intercellular gaps and exposure of basement membrane could be detected (original magnification $\times 3000)$. C, Some endothelial cells lost $(\times 600)$. 


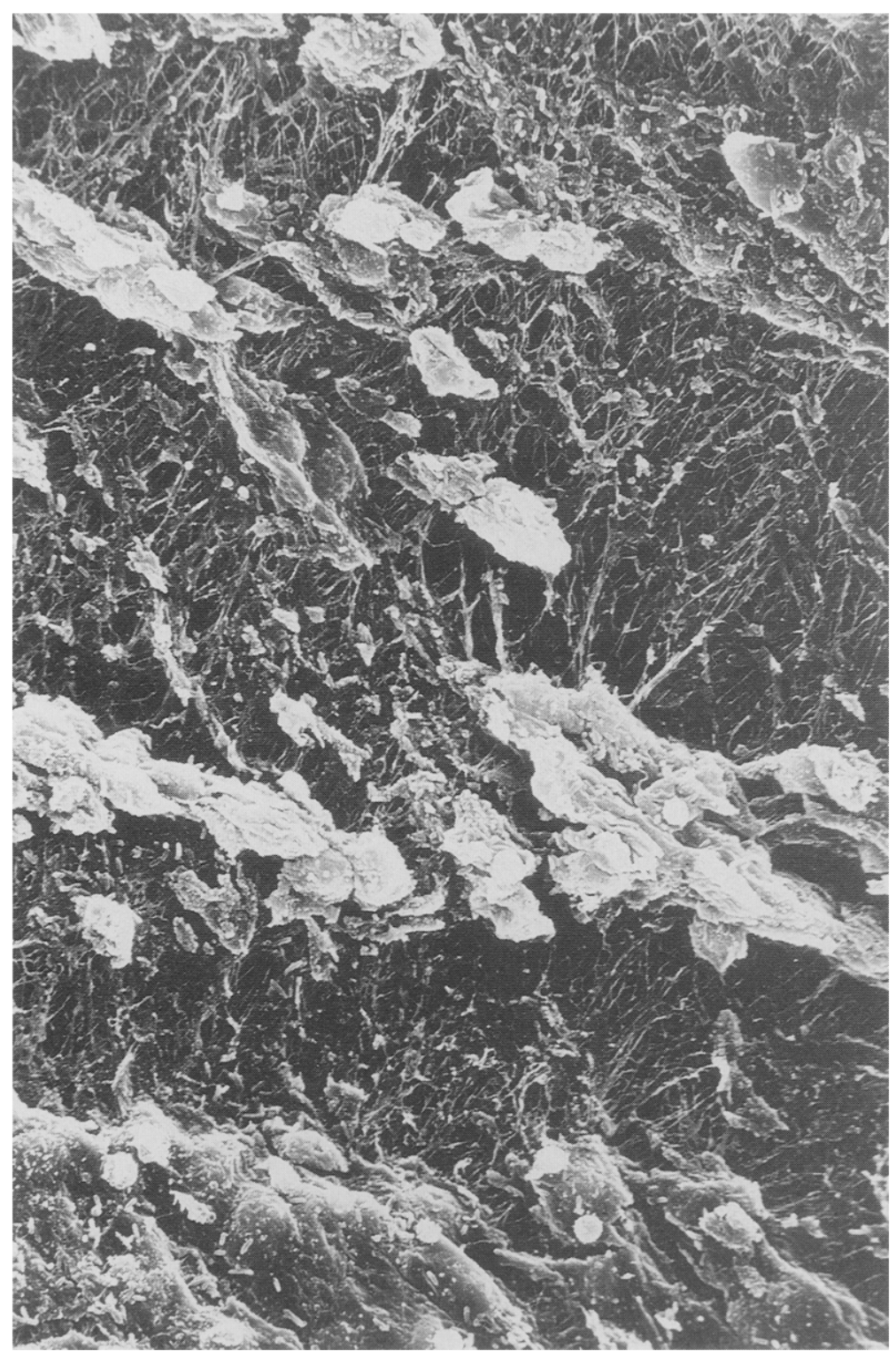

Fig. 6. SEM photograph of valves stored at $4^{\circ} \mathrm{C}$ in RPMI 1640 for 21 days. Most areas showed a complete exposure of fibers. Some remnant endothelial cells could be found, but they are shrivelled (Original magnification $\times 800$ ).

deterioration of the viability of the cells within 1 week of storage at $4^{\circ} \mathrm{C}$.

The main advantage of cryopreservation is that long-term storage can range from months to years. Preservation periods ranging from 10 years ${ }^{13}$ to 32,000 years ${ }^{14}$ have been suggested. Such long periods can only be achieved with the temperature limits below the glass transition point of the freezing solution, which is approximately $-130^{\circ} \mathrm{C} .{ }^{15}$ In this way, changes in the structure of frozen tissue can be avoided because chemical and physical processes are almost completely inhibited. The results of our study confirmed that a temperature below $-130^{\circ} \mathrm{C}$ is necessary for long-term preservation of the viability of the endothelial cells of heart valves. For as long as 2 weeks, the viability of the endothelial cells was similar whether stored at $-80^{\circ} \mathrm{C}$ or at $-170^{\circ} \mathrm{C}$ (Fig. 2). When valves are intended to be stored for 
such short periods, we recommend storage at $-80^{\circ} \mathrm{C}$ because this temperature offers practical advantages over storage at $-170^{\circ} \mathrm{C}$, which requires special tank filling with liquid nitrogen.

On the other hand, ice recrystallization has been detected at temperatures as low as $-130^{\circ} \mathrm{C}^{14,15}$ and was found to be accelerated at temperatures higher than $-130^{\circ} \mathrm{C}^{16}$ This could explain why after 4 weeks of storage at $-80^{\circ} \mathrm{C}$ the $\mathrm{PGI}_{2}$ production by the endothelium of cryopreserved valves significantly decreased in our experiments. In contrast, after 8 weeks of storage at $-170^{\circ} \mathrm{C}$, stimulated $\mathrm{PGI}_{2}$ production of the cryopreserved valves was not significantly reduced compared with fresh valves. FCS is commonly added to tissue culture medium as protein supplement ${ }^{17}$ because it is considered to induce RNA and DNA synthesis. ${ }^{18}$ For this reason, FCS is widely used in cryopreservation media for a variety of tissues and cells including human tissues. ${ }^{19-22}$ It has also been used to enhance viability of preserved aortic homograft valves. ${ }^{10,23}$ On the other hand, FCS is a potent heterologous antigen. ${ }^{24}$ In a previous study, we found that FCS was not required for cryopreservation of porcine aortic valves. ${ }^{3}$ In this study, we demonstrated the negative influence of FCS (loss of endothelial function during long-term cryopreservation). The results showed lower $\mathrm{PGI}_{2}$ release after bradykinin stimulation in valves stored at $-170^{\circ}$ for 6 months when FCS was used as a supplement in the medium (Table III). Although we cannot explain this observation, we can state that, contrary to what has been usually recommended, the addition of FCS to the cryopreservation medium is not advisable for maintaining the functional integrity of the endothelial layer.

From our results, we conclude the following: (1) Endothelial viability of aortic valve cusps is retained until 4 days of storage at $4^{\circ} \mathrm{C}$ but is remarkably decreased thereafter. Morphologic alterations appeared later. Viability of entire valve storage at $4^{\circ} \mathrm{C}$ should be assessed by measuring viability of endothelial cells because implanting a homograft valve with an apparently morphologically normal endothelial structure but with reduced or absent function might mean that the collagen-laying self-repair function of the underlying fibroblasts could also be disturbed. (2) There was no difference in $\mathrm{PGI}_{2}$ production after 14 days of cryopreservation at either $-80^{\circ} \mathrm{C}$ or $-170^{\circ} \mathrm{C}$. Although preservation at $-80^{\circ} \mathrm{C}$ is a more convenient technique for storage, liquid nitrogen vapor-phase storage at temperatures below $-130^{\circ} \mathrm{C}$ is required for long- term preserva- tion of endothelial function. (3) Not only is FCS unnecessary for short-term storage, it may actually be deleterious to the functional integrity of the endothelial cells.

We thank Dr. Ai H. Lin for her valuable assistance with the radioimmunoassay of 6-oxo-PGF $\mathrm{F}_{1 \alpha}$ and the laboratory personnel from the division of Electron Microscopy of University Instelling Antwerp, for their invaluable help with the scanning electron microscopy.

\section{REFERENCES}

1. Bodnar E, Matsuki O, Parker R, Ross DN. Viable and nonviable aortic homografts in the subcoronary position: a comparative study. Ann Thorac Surg 1989;47: 799-805.

2. Barratt-Boyes BG, Roche AH, Subramanyan R, Pemberton JR, Whitlock RM. Long term follow-up of patients with the antibiotic-sterilized aortic homograft valve inserted freehand in the aortic position. Circulation 1987;75:768-77.

3. Feng XI, van Hove CE, Mohan R, et al. Improved endothelial viability of heart valves cryopreserved by a new technique. Eur J Cardiothorac Surg 1992;6:251-5.

4. Lange PL, Hopkins RA. Allograft valve banking: techniques and technology. In: Hopkins RA, ed. Cardiac reconstruction with allograft valves. New York: Springer-Verlag, 1989:37-64.

5. Feng XJ, van Hove CE, Mohan R, Walter PJ, Herman AG. Effects of different antibiotics on the endothelium of the porcine aortic valve. J Heart Valve Dis 1993;2:694-704.

6. Salmon JA. A radioimmunoassay for 6-keto-prostaglandin $\mathrm{F}_{1 \alpha}$. Prostaglandins 1978;15:383-97.

7. Jaffe EA. Cell biology of endothelial cells. Hum Pathol 1987;18:234-9.

8. Hong SL. Effect of bradykinin and thrombin on prostacyclin synthesis in endothelial cells from calf and pig aorta and human umbilical vein. Thromb Res 1980;18:787-92.

9. O'Brien MF, Stafford G, Gardner M, et al. The viable cryopreserved allograft aortic valve. J Cardiac Surg 1987;2(Suppl 1):153-67.

10. Yankah AC, Hetzer R. Procurement and viability of cardiac valve allografts. In: Yankah AC, Hetzer R, Miller DC, et al, eds. Cardiac valve allografts 19621987. New York: Springer-Verlag, 1987:23-6.

11. Mochtar B, Van Der Kamp AWM, Roza-De Jongh EJR, Nauta J. Cell survival in canine aortic heart valves stored in nutrient medium. Cardiovasc Res 1984;18:497-501.

12. Al-Janabi N, Gibson K, Rose J, Ross DN. Protein synthesis in fresh aortic and pulmonary valve allografts as an additional test for viability. Cardiovasc Res 1973;7:247-50.

13. Luyet BJ. On various phase transitions occurring in 
aqueous solutions at low temperature. Ann N Y Acad Sci 1960;85:549-52.

14. Ashwood-Smith MJ, Farrant J. Low temperature preservation in medicine and biology. Tunbridge Wells, England: Pitman, 1980:22.

15. Dowell LG, Rinfret AP. Low temperature forms of ice as studied by x-ray diffraction. Nature 1960;188: 1144-8.

16. Karow AM, Pegg DE. Organ preservation for transplantation. New York: Marcel Dekker, 1981:118.

17. Leibfried-Rutledge ML, Critser ES, First NL. Effects of fetal calf serum and bovine serum albumin on in vitro maturation and fertilization of bovine and hamster cumulus-oocyte complexes. Biol Reprod 1986;35: $850-7$.

18. Supino R, Casazza AM, Di Marco A. Effect of daunorubicin and adriamycin on nucleic acid synthesis of serum stimulated mouse embryo fibroblasts. Tumori 1977;63:31-42.

19. Settmacher U, Jahn S, Grunow R, Mehl M, von Baehr R. Cryopreservation of newly formed human and mouse hybridoma cells. Allergy Immunol 1989;35: 195-201.

20. Dong JF, Detta A, Hitchcock ER. Susceptibility of human foetal brain tissue to cool- and freeze-storage. Brain Res 1993;621:242-8.

21. Muller-Schweinitzer E, Hasse J, Swoboda L. Cryopreservation of human bronchi. J Asthma 1993;30: 451-7.

22. Fisher RL, Hasal SJ, Sanuik JT, Scott KS, Gandolfi AJ, Brendel K. Cold- and cryopreservation of human liver and kidney slices. Cryobiology 1993;30: 250-61.

23. Gonzalez-Lavin L, Bianchi J, Graf D, Amini S, Gordon CI. Homograft valve calcification: evidence for an immunological influence. In: Yankah AC, Hetzer R, Miller DC, et al, eds. Cardiac valve allografts $1962-$ 1987. New York: Springer-Verlag, 1987:69-74.

24. Bodnar E, Olsen EG, Florio R, Guerreiro D, Ross DN. Heterologous antigenicity induced in human aortic homografts during preservation. Eur J Cardiothorac Surg 1988;2:43-7. 